\title{
ASSESSMENT OF PYTHON (Python bivittatus Kuhl.) HABITATS IN BARDIYA NATIONAL PARK, NEPAL
}

\author{
Bhuvan Keshar Sharma $^{1^{*}}$ and Ram Chandra Kandel ${ }^{2}$ \\ ${ }^{1}$ Pokhara University, Center for Postgraduate Studies, Kathmandu, Nepal \\ ${ }^{2}$ Bardiya National Park, Bardiya, Nepal \\ *Email: bhuvan_keshars@hotmail.com
}

\begin{abstract}
Habitats used by the Python (Python bivittatus) were studied in lowland areas of Bardiya National Park, Nepal. The main objective of the study was to assess the specific habitats used by Python in the Park. In association with key informants' survey to identify the potential habitats areas, field investigation was conducted and found out the specific sites. Among twenty habitat sites of Python, three were currently used and remaining other were found as potential habitats. In total, six specific habitats such as burrow or holes were mostly preferred by Python.
\end{abstract}

Key words: Python, block, buffer zone, potential habitat, current habitat, burrow.

\section{INTRODUCTION}

Habitat is spatial entity on the earth surface where an organism or community lives. The four major habitats of the biosphere are marine, estuarine, fresh water and terrestrial. Four basic components of habitat such as food, cover, water, and space should be available for the survival of a wildlife species in given habitat (Gopal 1992). The main determinant factors of habitat dynamics in an area are history of its establishment, climate, soil and anthropogenic activities (Taylor 1984). Python (Python bivittatus kuhl.), a non-venomous constrictor snake, is the largest living snake and lives on ground or in trees of tropical jungles or in dry rocky and sandy places. The one of the species of family Boidae found in Nepal is Python bivittatus. They may be diurnal and/or nocturnal depending on the amount of human induced disturbance in their associated environment. They largely feed on mammals, birds and reptiles but the most preferred is mammals (Majupuria 1982).

Bardiya National Park $\left(28^{0} 30^{\prime} \mathrm{N}, 81^{0} 15^{\prime} \mathrm{E}\right)$ is located in the Mid-Western Development Region, Bheri Zone and Bardiya District in the lowland area of Nepal. It is located in the subtropical biome of South Asia with a monsoonal climate covering $968 \mathrm{~km}^{2}$ area as core zone (GoN/MoFSC 2014). The physiography consists of Bhabar, alluvial flat land (Tarai), Churiya, and Riverine floodplain. The foothills of Churia are known as Bhabar. They are comparatively dry, consisting mainly of boulders, cobbles and coarse sand layers with moderate silt and clay. The Bhabar soils are well drained and relatively deep (Sharma 2014). The south-eastern section of the study area is the low-lying flat terrain of the Terai consisting of fine alluvial soil 
and loam. The Riverine floodplain contains coarse sand and fresh deposits of alluvial soil, silt and gravel (Sharma 1999).

There are three distinctive seasons, namely monsoon, cool and dry, and hot and dry, in the study area. Most of the annual precipitation occurs during four months of the year (late JuneSeptember). Churia is the origin of some streams which flow south-west as tributaries of the Geruwa Karnali and Babai rivers. Dhungre (Ghumna) Khola, Gainda (Patalchuli) Khola, Gitthe Nala and Hilenaro are other commonly known drainages of the study area. They are irregular and hold water during the monsoon period only (Sharma 1999).

Python bivittatus has been reported from west, central, and east Nepal. This is a jungle dweller occurring in dense as well as in open forests with rocky outcrops (Majupuria 1982). In the absence of forests, this snake species also occurs in rivers and ponds. It is distributed along the lowland areas of Indo-Chinese sub-region (Daniel 1989). The general distribution of this animal is available in different literatures (Majupuria 1982, Daniel 1989). Their specific habitats are not so specifically studied in Nepal. This study aims to identify the specific habitats used by Python in Bardiya National Park of lowland Nepal. The identified habitats may be currently used or be a potential habitats of Python in Bardiya National Park.

\section{METHODS}

\section{Block division}

For this study, overall area of Bardiya National Park was divided in to six blocks. The basis of block divisions were distance from water sources, diversity in forest type, disturbance from the anthropogenic activities and physiographic regions of the specific area.

The Karnali flood plain area was divided into five blocks. The northern part of this area is bit drier than the southern part, less diverse than the rest portion and included some portion of Chure in the north. So, the size of the northern block was larger than the other blocks of Karnali flood plain. Similarly, the southern portion of the Karnali flood plain outside core protected areas is receiving more anthropogenic activities. The central portion of this flood plain area incorporated the potential habitats for this animal. So, those areas were divided in three blocks. From the central portion of this National Park, Babai river is trespassing from north to south direction. This formulated narrow valley and called as Babai valley. The whole Babai valley is situated in the Churiya physiographic region and considered as one block. The name of the blocks and the specific site is as follows:

Block I: This block included buffer zone areas at south from Elephant stable of Bardiya National Park (BNP) to the border of India. This area is quite disturbed from different anthropogenic activities.

Block II: This block accumulated areas between the Elephant stable of BNP in south and Tiger (Bagh) Machan in north. This block included a narrow strip of BNP surrounded by its buffer zones in east, south and west direction. In this block more than $50 \%$ area are riverine forest.

Block III: This block is distributed between Tiger Machan in south and Rhino (Gainda) Machan in north. Located in Bhabar region, this area included Sal forest and a narrow strip of disturbed riverine forest.

Block IV: Area between Rhino Machan in south and Hog deer (Laguna) Machan in north is considered as block VI. Its larger area was occupied by Sal forest with narrow strip of disturbed riverine forest. It is located in Bhabar region.

Block V: This is the area of BNP at north from Laguna Machan. It included both Bhabar and 
Churiya regions. Most of its area was occupied by Sal forest.

Block VI: This block included the whole Babai valley in the north-eastern part of BNP. It included Churiya region with hill sal dominated forest.

General information regarding location, history, and climate of the study area were obtained from secondary sources. The main sources of information were publications, concerned authorities and local people. The main authorities for concerned data are Bardiya National Park, National Trust for Nature Conservation (NTNC) and the Department of National Parks and Wildlife Conservation (DNPWC).

\section{Information collection}

A preliminary reconnaissance survey was performed to get general information of the area and general habitats. To gather information about the available habitats of Python in the study area, ground surveys were carried out to locate burrows and dwelling sites with the help of experienced and knowledgeable persons and those were also interviewed as key informants (Mikkelsen 1995).

The key informants for this study were the people regularly visiting the forest areas. The main informants were elephant stable personnel, nature guides, game scouts and researchers. The available sites of Python were identified from the group as well as individual discussion. Checklists focusing about the season of more frequent observation, time of frequent observation, incubation sites with habitat types, distance of water sources from the observed place and their foraging habitats were prepared. The information was collected based on those checklists. The identified sites from the discussion were visited to get the field level information regarding the habitat of Python.

The main primary data were collected directly during field surveys. Visual Encounter Survey Protocol (Corn and Bury 1990, Heyer et al. 1994) is used to assess the status and presence of Python in terms of encounter rate. During the field visit, Python habitat data were collected. Such information were incorporated along with the information on the locality of the observed sites, geographical location by using Geographical Positioning System, altitude, distance from water source, specific location where the animal was observed and its surrounding habitats around $50 \mathrm{~m}$ and $100 \mathrm{~m}$ distances.

\section{Habitat categories}

The potential and used habitats of the animals were divided in five categories. They were forest, shrub land, grass land, river bed and river.

The forest habitat was further categorized in five sub-types based on the species composition and geometry of the tree distribution (Sharma et al. 2012, Yadav et al. 2013). Forest either distributed in the moist area having lianas and shrub or located near by the river or with both characters was categorized as riverine forest. The species composition in the tree canopy of this forest was deciduous broad-leaved or evergreen. The forest having Sal (Shorea robusta) as dominating species in the canopy layer was considered as Sal forest. This forest was mostly distributed in the area having stable and thick layer of soil. Forest with the mixed type of species in the canopy layer was considered as mixed forest. Area with the scattered trees and less than $10 \%$ crown cover was considered as savannah. Forest area having open land around $50 \mathrm{~m}$ distance and with different types of species in the canopy layer around $100 \mathrm{~m}$ distance was considered as other categories of forest (Yadav et al. 2013).

The area with the shrub covering more than $50 \%$ land area was considered as shrub land. An area dominated with grasses was considered as grass land. The grass land incorporating the grasses which were lower than the height of the breast was considered as short grass land. Seasonal inundated areas near the river were considered as river bed and the area with permanent running water was considered as river (Sharma 1999).

Area around the directly observed animal was considered as current habitat. An area where the animal was previously recorded or areas having indirect evidences were considered as potential habitats. 


\section{RESULTS AND DISCUSSION}

The current habitats of Python incorporated riverine forest, shrub land and short grass land. The observation frequency of these animal was equal $(33.3 \%$ each) in all those habitats. Mixed forest, savannah and shrub land were found more potential habitats for this animal. Similarly, other forest, short grassland and river were less potential habitats. Least potential habitats of this animal were Sal forest and river bed (Table 1)

After acquiring the information from key informants and group discussions 20 sites of the potential habitats of Python were visited. The numbers of visited sites were highest in the Block II followed by Block V, VI and III (Table 2). The numbers of visited sites were used by Python in the past based on the information provided from Key informants and group discussion. The evidences regarding the availability of this animal were less in Block I and IV and these blocks were not visited.

\section{Distribution of specific habitats}

They usually conceal inside the burrows. Some of them were also found hiding in the dense coverage of shrub species. During the hot season (April to June) and monsoon (July to August) they were less frequently observed. During those periods they preferred to hide inside water to escape form hot weather. So, they were observed either inside the water or near the water sources during hot season.

All four basic components of habitat like food, cover, water, and space (Gopal 1992) were available in each block of the study area. But, their occurrence was limited to the area having enough food, hiding places with less anthropogenic activities and water (Table 3 ).

The most common food of Python in Bardiya National Park included spotted deer, hog deer, rhesus monkey, peacock and jungle fowl. One incident of unsuccessful capture of the human being was also reported from the area. The food items of this animal were distributed in almost all parts of the park. Though Python of BNP are less active during winter season, November to February, they used to come out from its hiding place to the sun light around 9:00 to 10:00 in the morning. They also capture their food items in these less active days. So, there was not hibernation period for the Python in BNP. They found active even during the winter season. Commonly they captured their prey near the tree trunks.

Table 1. Types and utilization of the habitats by Python in BNP.

\begin{tabular}{rlcccc}
\hline SN & Habitat types & \multicolumn{2}{c}{ Current habitats } & \multicolumn{2}{c}{ Potential habitats } \\
& & Frequency & Percent & Frequency & Percent \\
\hline 1. & Forest & & & & -- \\
& a) Riverine & 1 & 33.3 & -- & 5.9 \\
& b) Sal & -- & -- & 1 & 17.6 \\
& c) Mixed & -- & -- & 3 & 17.6 \\
& d) Savannah & -- & -- & 3 & 11.8 \\
& e) Other & -- & -- & 2 & 17.6 \\
2. & Shrub land & 1 & 33.3 & 3 & 11.8 \\
3. & Short grass land & 1 & 33.3 & 2 & 5.9 \\
4. & Riverbed & -- & -- & 1 & 11.8 \\
5. & River & -- & -- & 2 & 100.0 \\
\end{tabular}


Table 2. Distribution of Python habitats in different blocks in BNP.

\begin{tabular}{lccc}
\hline Blocks & \multicolumn{2}{c}{ Habitat categories } & Total \\
& Potential & Current & \\
\hline Block I & 0 & 0 & 0 \\
Block II & 9 & 3 & 12 \\
Block III & 2 & 0 & 2 \\
Block IV & 0 & 0 & 0 \\
Block V & 3 & 0 & 3 \\
Block VI & 3 & 0 & 3 \\
Total & 17 & 3 & 20 \\
\hline
\end{tabular}

Table 3. Specific habitats used by Python in the study area.

\begin{tabular}{lcccc}
\hline Specific habitats & \multicolumn{1}{c}{ Block II Block III Block V Block VI } \\
\hline Burrow or holes & 10 & 1 & 3 & 0 \\
Buttress of live tree & 1 & 0 & 0 & 0 \\
Dense bush & 1 & 0 & 0 & 0 \\
Embankment & 0 & 1 & 0 & 0 \\
Rock & 0 & 0 & 0 & 1 \\
Water & 0 & 0 & 0 & 2 \\
Total & 12 & 2 & 3 & 3 \\
\hline
\end{tabular}

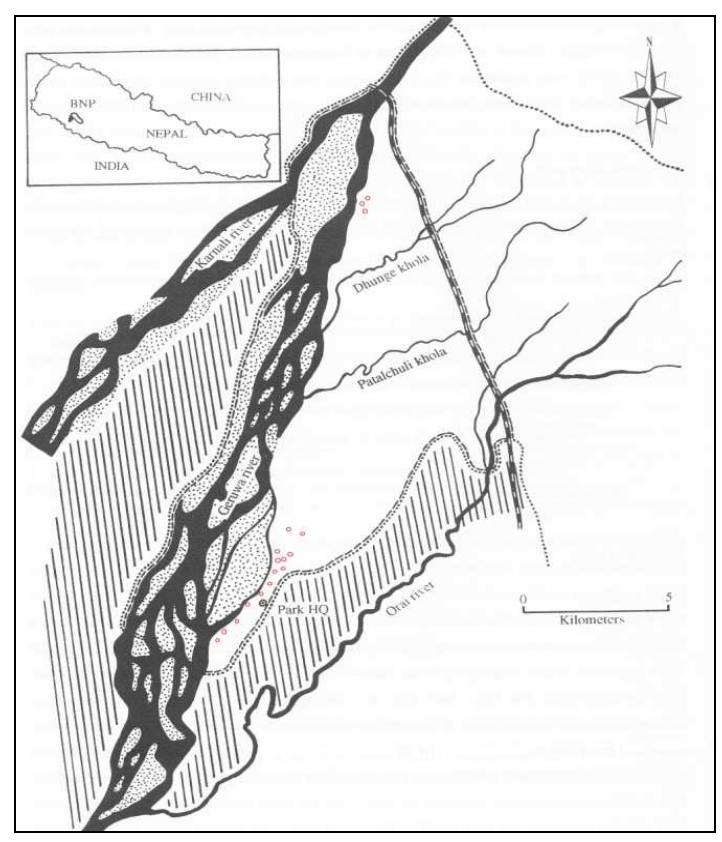

Fig. 1. Distribution map of Python habitats in survey sites of BNP, marked with red circle.
Burrows or holes were more frequently used habitats by Python. During the hot and monsoon seasons (April to August) they utilize water as their habitats. Less frequently they were using the other habitats like buttress of live tree, dense bush, rock and embankment (Fig. 1).

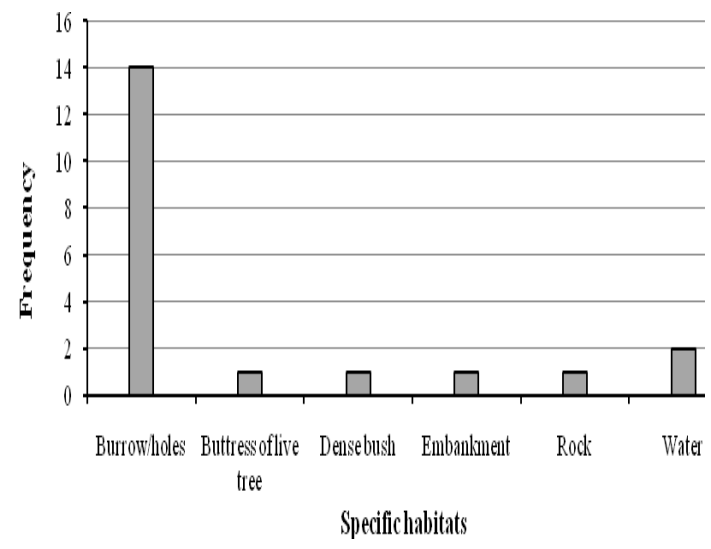

Fig. 2. Used frequency of specific habitats by Python.

\section{CONCLUSION}

Pythons are distributed in the lowland areas in the Bardiya National Park. This study has found out the preliminary result of distribution pattern and aggregation sites of Python bivittatus in potential habitats at BNP. Basic data on habitats requirement such as burrows, defaults, crevices, holes are generated from this study. Though the potential habitats of Python are forest, shrub land, grassland, river and river bed, currently they are using forest, shrub land and grassland only. Preferred specific habitats of Python are burrows or holes. They were the major residence of the areas having permanent water sources and forest area nearby. Understanding the habitat use, distribution and ecology of Python bivittatus is equally important for developing species conservation action plan for the effective conservation and management of this species in the Park. 


\section{ACKNOWLEDGEMENT}

Bardiya National Park is acknowledged for allocating fund for the study. Thanks to Mr. Ashok Bhandari, Assistant Warden of BNP for his support and suggestions for the work. Security battalion of BNP, Narasingh Dal Gana, is acknowledged for their immense help. Mr. Rabin Kadariya, In-Charge of Bardiya Conservation Program, is acknowledged for providing Raft and wildlife technician to study in Babai valley. Mr. Chandra Man Tamang, In-Charge and other staffs of the Elephant Stable in Bardiya National Park are acknowledged for sharing information about the occurrence of Python and providing elephants on time. Thanks to Game Scout of BNP Mr. Indra Prasad Jaisi for sharing the information regarding distribution of Python and accompanying and raiding Raft safely in Babai valley. Mr Ram Raj Chaudhary of NTNC and and Mr Chandra Bahadur Oli of BNP are acknowledged for accompanying and help for data collection in Babai valley.

\section{REFERENCES}

Corn, P.S. and R.B. Bury. 1990. Sampling Methods for Terrestrial Amphibians and Reptiles. USDA Forest Service, General and Technical Report, PNW-GTR-256, 34 pp.

Daniel, J.C. 1989. The Book of Indian Reptiles. Bombay Natural History Society, Bombay, India.

GoN/MoFSC. 2014. Nepal Biodiversity Strategy and Action Plan 2014-2020. Government of Nepal, Ministry of Forest and Soil Conservation, Kathmandu, Nepal, pp. 232.
Gopal, R. 1992. Fundamentals of Wildlife Management. Justice Home, India.

Heyer, W.R., M.A. Donnelly, R.W. McDiarmid, L.C. Hayek and M.S. Foster (eds.). 1994. Measuring and Monitoring Biological Diversity. Standard Methods for Amphibians. Smithsonian Institution Press, Washington, DC, 364 pp.

Majupuria, T.C. 1982. Wild is Beautiful. S Devi, India.

Mikkelsen, B. 1995. Methods for Development Work and Research. Sage Publications, New Delhi, India.

Sharma, B.K. 1999. Wildlife Habitat Mapping by Using Geographic Information Systems (GIS) in the Karnali Floodplain of Royal Bardia National Park at Lowland Nepal. M.Sc. Thesis submitted to Agricultural University of Norway.

Sharma, B.K. 2014. Bio-resources of Nepal. Subidhya Sharma, Kathmandu, Nepal, 811 p.

Sharma, B.K., M.K. Chalise and G.S. Solanki. 2012. Vegetation types and wildlife occurrence in Baghmara Buffer Zone Community Forest, Nepal. International Multidisciplinary Research Journal 2(2):5265.

Taylor, J.A. 1984. Themes in Biogeography. Croom Helm, London.

Yadhav, B.R., I.C. Dutta, M.K. Chalise, C. Williums and B.K. Sharma. 2013. Habitat utilization by Asiatic Wild Elephant (Elephus maximus) in Parsa Wildlife Reserve, Nepal. Ecoprint 20:41-52. 